\title{
Relationship Between Corporate Governance and Corporate Social Responsibility: Evidence From Nepalese Commercial Banks
}

\author{
Resam Lal Poudel
}

\begin{abstract}
ABSTACT
The research paper aims to show the relationship between corporate governance $(C G)$ and corporate social responsibility (CSR) disclosure in Nepalese commercial banks. In simple terms corporate governance is the system by which companies are governed. It is a set of rules and behaviors according to which companies are managed and controlled. Corporate social responsibility or sustainability is an important feature in contemporary business addresses different aspects like business ethics, stakeholder's management and social performance. Effective corporate governance is expected to support effective and efficient corporate social responsibility within commercial banks. The content analysis of 10 commercial banks composing 5 Joint Venture (JV) Banks and 5 Non Joint Venture (NJV) Banks though judgmental sampling method based on stratified sampling technique was used to extract CSR disclosure items and corporate governance factors from secondary data specifically annual report for the period of one year. T-test was employed to test the level of significance. Regression analysis was used to examine the relationship between corporate social responsibility disclosure and independent variables associated with corporate governance practices. The study reveals that different variables associated with corporate governance practices are positively and significantly correlated with the level of corporate social responsibility initiatives based on all three models. The paper is useful to organization and statutory bodies to take consideration of corporate governance practices which will enhance corporate social responsibility initiatives.
\end{abstract}

Keywords: Corporate governance, corporate social responsibility, corporate social responsibility reporting, regulatory bodies, stakeholders theory.

\section{Introduction}

Corporate governance (CG) indicates the policies and procedures applied by firms to attain certain sets of objectives, corporate missions and visions with regard to stockholders, employees, customers, suppliers and different regulatory agencies and the community at large. The role of governance is to maximize shareholder's wealth. Corporate governance depends on managerial performance as well as a consideration of social responsibility, the socio- cultural-environmental dimension of business procedure, legal and ethical practices with a focus on customers and other stakeholders of an organization. Corporate governance is gaining importance among policy makers, entrepreneurs, business personnel, stakeholders and related organizations.

Corporate Social Responsibility (CSR) is an increasingly important part of the business environment. The past twenty years have seen a radical change in the relationship between business and society. Key drivers of this change have been the globalization of trade, the 
increased size and influence of companies, the repositioning of government and the rise in strategic importance of stakeholder relationships, knowledge and brand reputation. The relationship between companies and civil society organizations has moved on from paternalistic philanthropy to a re-examination of the roles, rights and responsibilities of business in society. Corporate Social Responsibility (CSR), defined in terms of the responsiveness of businesses to stakeholders' legal, ethical, social and environmental expectations, is one outcome of these developments.

CG is a well-defined concept related to profit maximization and protection of those economic agents who have provided capital to the firm. CSR is defined less precisely. It evokes a concept apparently in contrast with profit maximization because it suggests a set of actions, which is beneficial to some external stakeholders and may conflict with the interest of the shareholders.

After the increasing of corporate social responsibility awareness, CSR becomes an important communication mechanism among the company, stakeholders and investors (Hong \& Kacperczyk, 2009). Corporate Social Responsibility reporting is a part of accountability in the context of corporate governance, since the disclosure of the environmental issues might give potential impact on the welfare of the shareholders. It can also be considered as one element of corporate governance (Kassinis \& Vafeas, 2002). Corporate Social Responsibility was considered as a significant force for achieving longterm goals especially in building a harmonious society in the long term (Lin, 2010), due to a strong commitment in corporate social responsibility was positively related to good corporate governance (Ho, 2005).

The paper incorporates stakeholder's theory. Stakeholder theory provides no effective standard against which corporate agents can be judged. Balancing stakeholder interests is a ill-defined notion, which cannot serve as an objective performance measure; managers responsible for interpreting as well as implementing it are effectively left free to pursue their own arbitrary ends. Stakeholder theory on looks at corporate governance beyond the spectrum of just shareholders and directors, by taking into consideration the importance of other stakeholders -a stakeholder is any person or group of individuals that are affected directly or indirectly by the activities of the company (Mallin, 2010) for example, employees, creditors, suppliers, customers, local communities, environmental groups and government.

The aim of this paper is to examine the relationship between corporate social responsibility disclosure and corporate governance disclosure by Nepalese commercial banks. This paper is significantly important to develop framework of corporate social responsibility and corporate governance. This study is equally important for regulatory bodies and concerned authorities to develop framework of CG and CSR.

\subsection{Literature Review}

Beltratti(2005) studied the complementarity between corporate governance and corporate social responsibility. The available empirical evidence shows that both CG and CSR are positively related to the market value of the firm. Research finding indicates that corporate governance has significant positive effect to corporate social responsibility. Besides the shareholders rights, the responsibility of the board of commissioners, the protection of the stakeholders' interests, disclosure and transparency are also important indicators that 
form the practice of corporate governance in public companies in Indonesia. Corporate social responsibilities activities tend to focus on internal stakeholders by establishing good relations with the workers as well as working on the protection and improvement of the environment. This finding implied that the company is actively building stakeholder relations and had already considered the issue of sustainability by improving its social performance. (Ali and Atan, 2013) examined the relationship between CG and CSR disclosure of Malaysian and global companies. Descriptive analysis and Kruskal Willis test indicated significant differences in the extent and variety of CSR disclosure among Malaysian and Global companies. While multiple regression analysis results indicated that board size, board independent and ownership concentration show significant relationship with the extent of CSR disclosures. Both of the control variables (firm size and leverage) found not significantly related to the extent of CSR disclosures.

Li( 2014) Based on 387 responses from small corporations, the results show that corporate governance bundles measured by the extant literature, has a negative impact on the CSR of small corporations, which may be explained by the Stakeholder Theory and the ResourceDependency Theory. The results call for a stakeholder treatment to the governance needs in small corporations in Australia. Wise and Ali (2009) of the three cases examined in their study, two are relatively new entrants to the banking sector. They observed that the newest firm, incorporated in 1999, made no disclosures in regards to its corporate social responsibility and, as a consequence, conclude that the corporate governance mechanisms in this firm are likely to be unsophisticated. (Wang et.al, 2013) through literature review and causal feedback loop analysis of system dynamics, they found that among corporate governance, corporate social responsibility and financial performance, corporate governance is the pivot. Financial performance feedback influences the selection of successors and corporate governance, morality and human caring are the key factors. Corporate social responsibility and corporate governance positively influence reputation. There are positive and negative effects of corporate social responsibility on corporate operational efficacy. The main contribution of this study is to demonstrate morality and human caring as the key factors since morality and human caring both influence the selection of successors, corporate governance and corporate social responsibility and they become the critical indicators to evaluate the enterprises' successors.

\section{Data and Methods}

The study comprises all the commercial banks running in Nepal as a population. Judgmental sampling technique has been employed. The stratified technique is based on strata according to bank type as Joint Venture (JV) and Non Joint Venture (NJV). The sample size consists of ten commercial banks, five each from JV and NJV commercial banks. The study employs secondary sources of data, mainly annual report of those commercial banks. CSR and CG relationship is based on CSR and CG score determined by the researcher himself. As far as possible researcher uses definite measures to determine CSR and CG score. Those score has been determined on the basis of importance given to CSR and CG in mission and vision statement, CEO's message, Chairman's message, size of directors, representation of audit committee. However those CG and CG score were determined by the researcher himself on the basic of 1-5 score. The CG and CSR score and relationship among them has been presented following descriptive research design. Those score and relationship has been presented in the form of chart, mean, correlation, independent sample t-test and regression analysis 
The relationship between CG and CSR has been analyzed with the help of regression model. The model specification has been presented below.

$\mathrm{CSRi}=\alpha+\beta$ 1CGscorei $+\mathrm{ei}$

Where,

CSRi $=$ CSR score bank I

CGscorei=CG score of bank i

$\mathrm{Ei}=$ random error term

$\alpha=$ Constant

$\beta=$ regression coefficient

\section{Disussion and Analysis}

Figure I: CG and CSR Score of bank type

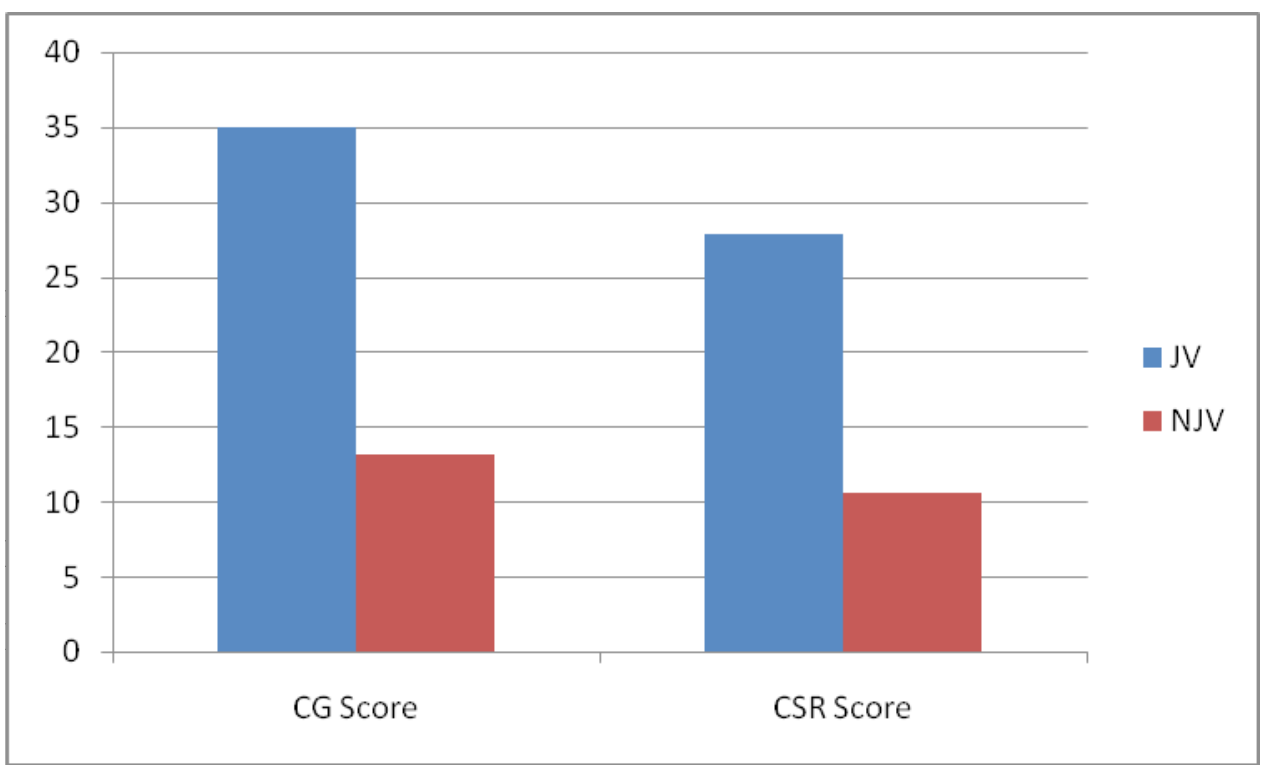

Figure I shows CG and CSR score according to bank type, Joint Venture and Non Joint Venture. The CG and CSR score of joint venture bank is better than that of non joint venture banks. It indicates that joint venture commercial banks of have given more importance on CG guidelines issued by central bank. Similarly, joint venture commercial banks of nepal has given more priority in CSR initiatives.The CSR score has also been determined on the basis of the importance given to CSR initiatives by respectives banks.

Figure II shows five determinant factor of CG according to bank type. It clearly indicates that joint venture commercial banks in nepal has given more importance on CG factors. Regularity and frequency of board meeting, higher remuneration to directors, combination of audit committee, higher number of board committee and lesser number of board of directors has been assigned higher CG score. 
Figure II: Determinant factors of CG according to bank type

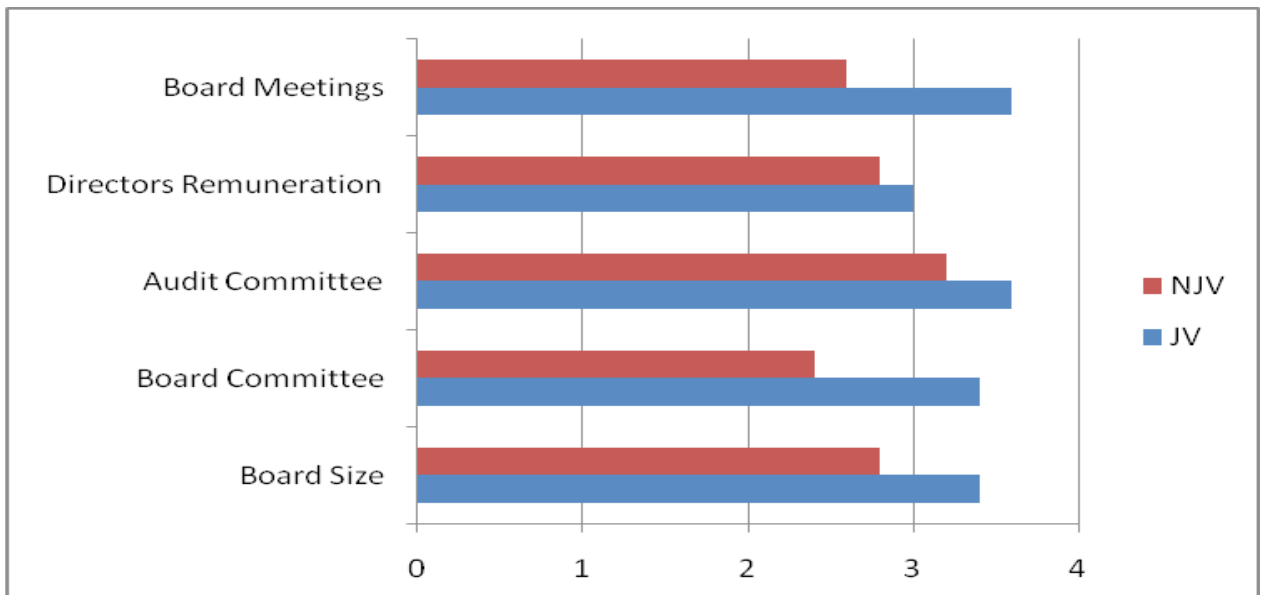

Table I: Output of Independent Sample T-test

\begin{tabular}{|l|c|c|c|c|c|}
\hline & \multicolumn{2}{|c|}{ Mean Score } & & & \\
\hline & JV & NJV & T & d.f & Sig \\
\hline CG & 35 & 27.8 & 1.243 & 8 & 0.249 \\
\hline CSR & 13.2 & 10.6 & 0.881 & 8 & 0.404 \\
\hline H1: There is no significant difference in mean score of CG by bank type \\
H2: There is no significant difference in mean score of CSR by bank type \\
\hline
\end{tabular}

Table I shows mean score of JV banks and NJV banks. It mainly presents the output of independent sample t-test. The CG and CSR mean score of joint venture is higher than that of NJV banks. It indicates that, the CG pattern of JV is better than that of NJV. It means more importance is given to CG component and CSR initiatives by JV in Nepalese context. The t-value shown in the table indicates the test is insignificant which reject alternate hypothesis and accept null hypothesis. It indicates that the CG and CSR score of JV and NJV banks are not statistically different to mean score.

Regression model output has been presented in Table II. In each model CSR has been taken as dependant variable and CG as an independent variable. The main hypothesis of model I is that bank with better CG practices have higher CSR initiatives. The first model presents regression output of all bank type, JV banks in model II and NJV in model III.

In the first model, t-test is significant at $1 \%$ significance level. It means that CG score is related with CSR initiatives. . Moreover beta is positive which reflect CG score is positively related with CSR initiatives. If banks adopt better CG practices CSR initiatives also increase for the welfare of the society. $\mathrm{R}^{2}$ of 0.719 means that around $72 \%$ variations in CSR score is explained by CG score. The higher value of $\mathrm{R}^{2}$ indicates CG and CSR are highly correlated.

In the second model, t-test is significant at $10 \%$ significance level. It means that CG score is related with CSR initiatives. A good CG practice has lead to CSR initiatives by most of 
the joint venture banks. Moreover beta is positive which reflect CG score is positively related with CSR initiatives by JV commercial banks. If JV banks adopt better CG practices CSR initiatives also increase for the welfare of the society. $\mathrm{R}^{2}$ of 0.691 means that around $69 \%$ variation in CSR score is explained by CG score in joint venture commercial banks.. The higher value of $\mathrm{R}^{2}$ indicates $\mathrm{CG}$ and CSR are highly correlated. This finding is almost similar to the correlation of CG and CSR of 0.83 .

Table II: Output of regression model

\begin{tabular}{|l|c|c|c|}
\hline & Model I (All Bank Type) & Model II(JV) & Model III(NJV) \\
\hline C & $\begin{array}{c}-1.101 \\
(-0.368)\end{array}$ & $\begin{array}{c}1.478 \\
(0.316)\end{array}$ & $\begin{array}{c}-5.463 \\
(-1.085)\end{array}$ \\
\hline CG Score & $\begin{array}{c}0.414 \\
(4.552)^{*}\end{array}$ & $\begin{array}{c}0.335 \\
(2.592)^{* * *}\end{array}$ & $\begin{array}{c}0.578 \\
(3.292)^{* *}\end{array}$ \\
\hline $\mathrm{R}^{2}$ & 0.719 & 0.691 & 0.783 \\
\hline Adj. $\mathrm{R}^{2}$ & 0.684 & 0.588 & 0.711 \\
\hline $\mathrm{F}$ & $20.447^{*}$ & $6.716^{* * *}$ & $10.838^{* *}$ \\
\hline $\begin{array}{l}*, * * * * * \\
\text { respectively. Mean the values in parentheses are t-statistics }\end{array}$ \\
\hline
\end{tabular}

In the third model, t-test is significant at $5 \%$ significance level. Beta is positive which reflect CG score is positively related with CSR initiatives by NJV commercial banks. If N JV banks adopt better CG practices CSR initiatives also increase for the welfare of the society. R2 of 0.783 means that around $79 \%$ variation in CSR score is explained by CG score in NJV banks.. The higher value of $\mathrm{R}^{2}$ indicates CG and CSR are highly correlated. This finding is almost similar to the correlation of CG and CSR of 0.88. From the following analysis it has been revealed that there is higher relation between CG and CSR initative in NJV banks.

\section{Conclusions and Recommendations}

Corporate Governance and Corporate Social Responsibility are the two sides of a same coin. The study reveals that CG and CSR score of JV banks are higher which indicates that there has been good practice of CG and CSR initiatives in JV banks. The t-test indicates that the CG and CG score of JV and NJV are not significantly difference to mean score. The positive beta coefficient in the three models indicates positive relation. The higher beta coefficient of NJV banks indicates that if those banks focus more on CG practices, it will also increase CSR initiatives. This finding indicates CSR initiation will in turn satisfy all stakeholders. The correlation coefficient and $\mathrm{R}^{2}$ in each model signifies positive relation between CG practices and CG initiatives. Specially, in case of NJV the higher practices of good CG practices will also increase CSR initiatives in the future.

The result from this study has provided the evidence and motivation to all commercial banks in Nepal to take a serious view in the implementation of good governance and thus contribute more to the corporate social responsibility. There can be a lot of advantages 
Relationship Between Corporate Governance and Corporate Social Responsibility ...

and benefits for companies especially with good corporate social responsibility disclosure either in or outside Nepal. This study has proven the importance of the corporate governance characteristics in influencing the level of the CSR initiatives for the Nepalese commercial banks. The study has also proved that regulatory guidelines are not sufficient. Therefore regulatory bodies should focus more on these two components. Similarly commercial banks may increase their corporate image through better corporate governance practices. This study has focused only on specific banks on judgmental basis so further study can be conducted on other sectors. The future study may also be conducted finding the relationship between CG and CSR on the basis of primary data specially questionnaire.

\section{BIBLIOGRAPHY}

Ali, M. M., \& Atan, R. H. (2013). The relationship between corporate governance and corporate social responsibility disclosure: a case of high malaysian sustainability companies and global sustainability companies. South East Asia Journal of Contemporary Business, Economics and Law, 3(1)

Beltratti, A. (2005). The complementarity between corporate governance and corporate social responsibiliy. The International Association for the Study of Insurance Economics, The Geneva Papers, 30, (373-386)

Chen, V. Z., Li, J., \& Shapiro, D. (2011). Are oecd-prescribed good corporate governance practices really good in an emerging economy?. Asia Pacific Journal Management, 28, 115138

Cheung, Y., Jiang, K., \& Tan, W. (2012). Doing-good' and 'doing-well' in Chinese publicly listed firms. China Economic Review, 23, 776 - 785

Frankental, P. (2001). Corporate social responsibility - a pr invention?. Corporate Communications: An International Journal, 6 (1), 18- 23

Ho, C. (2005). Corporate governance and corporate competitiveness: an international analysis, corporate governance. An International Review, 13 , 211-253

Hong, H., \& Kacperczyk. M. (2009). The price of sin: the effect of social norms on markets. Journal of Financial Economics, 93, 15-36

Kassinis, G., \& Vafeas, N. (2002). Corporate boards and outside stakeholders as determinants of environmental :itigation. Strategic Management Journal, 23 (5), 399-415.

Li, Y. (2014). The impact of corporate governance on the corporate social responsibility of small corporation in australia: a structural equation modeling approach. WEI International Academic Conference Proceeding, New Orleans, USA

Lilik, H., Bambang, S., \& Erwin, S., (2012). Are indonesian corporate really ethical? Exploring corporate governance and corporate social responsibility linkage. Doctoral Program of Accounting Science. Malang, Indonesia 
Lin, L. (2010). Csr in china: window dressing or social change. Berkeley Journal of International Law, 20 (1), 64-100

Mallin, C. A. (2010). Corporate governance. Oxford Press.

Margolis, J. D., Elfenbein, H. A., \& Walsh, J. P. (2007). Does it pay to be good? A meta analysis and redirection research on the relationship between corporate social responsibility and financial performance. Working paper, Harvard University.

Mihaela, D., Iulian, S., \& Ileana, C. (2012). Corporate governance and social responsibility aspects in top ten it companies. In the Context of Globalization, 46(23), 121-124

Money, K., \& Schepers, H. (2007). Are csr and corporate governance converging: a view from boardroom directors and company secretaries in ftse 100 companies in the UK. Journal of General Management , 33(2), 1-11.

Wang, K., Chi, C., \& Chiu, M. (2013). Exploring the relationship among corporate governance, social responsibility: a perspective of the enterprises selection of successors. Research Notes in information science, 13(13).

Wise, V., \& Ali, M. (2009). Corporate governance and corporate socialresponsibility in bangladesh with special reference to commercial banks. AIUB Bus Econ Working Paper Series. Retrived from http://orp.aiub.edu/WorkingPaper/ WorkingPaper.aspx?year=2015 